Annales Missiologici Posnanienses t. 24 (2019), s. 59-74

doi: $10.14746 / \mathrm{amp} .2019 .24 .4$

ORCID: 0000-0002-7997-8364

JUSTYNA PYZ

Uniwersytet Jagielloński

Wydział Historyczny

\title{
Roberto de Nobili SJ i misja w Maduraju w latach 1606-1656
}

Maduraj to miasto w południowych Indiach, stanowiące ważne centrum religijne. W XVII wieku było ono ośrodkiem ze znaczącymi wpływami braminów, którzy gromadzili się wokół świątyni bogini Minakszi (Chandler 11). Trudno wyobrazić sobie bardziej wymagające miejsce dla misjonarskiej działalności. Misje chrześcijańskie w Indiach skupiały się zwykle na niższych kastach, dla których zmiana religii nie stanowiła utraty statusu społecznego. Nawet Franciszek Ksawery nie zdołał nawrócić nikogo w Maduraju (Walsh 94).

\section{Misja prowadzona przez Gonçala Fernandesa}

Bezpośrednio przed przyjazdem Roberta de Nobili do Maduraju jedynymi chrześcijanami w mieście byli Portugalczycy oraz garstka niezamożnej ludności przybyłej z wybrzeża. Do pracy z nimi przydzielony został Gonçalo Fernandes, który przybył z Portugalii jako dwudziestoletni żołnierz. Misjonarz podczas 11 lat w Maduraju nie nawrócił ani jednej osoby. Otworzył jednak przychodnię, z której korzystali zarówno hindusi, jak i chrześcijanie, oraz szkołę, zatem przyczynił się do poprawy warunków życia ubogiej ludności. W raporcie na temat braminów nie potrafił przedstawić ich wierzeń religijnych, natomiast dosyć wiernie opisał ich styl życia i zwyczaje, co oznacza, że miał z nimi kontakt. Jednak „Fernandesa poważnie ograniczało przekonanie, że wszyscy Europejczycy są lepsi od Indusów, oraz, że Portugalczycy są lepsi od wszystkich innych Europejczyków" (Neill 1984, 280). Jako jeden z wielu akceptował również nazwę: parangi, którą byli określani przybysze z Europy. Słowo to w jego mniemaniu stanowiło synonim Portugalczyka i chrześcijanina. „W najbardziej ujmujący sposób zapraszał wysokiej klasy Hindusa, aby 
przyjął religię parangi i kiedy jego zaproszenie spotykało się ze wzgardą, nie mógł znaleźć innego wyjaśnienia niż ignorancja tych biednych ludzi, którzy nie potrafili docenić, co było dla nich dobre" (Sauliére 44). Jednakże dla hindusów słowo to oznaczało osobę spoza kasty, nieczystą i na najniższym poziomie społecznym.

W 1606 r. dołączył do niego młodszy współbrat Roberto de Nobili. Ignacy Loyola radził wszak, by na dalekie misje wysyłano dwóch braci, którzy różnią się charakterami, co uzasadniał następująco:

Komuś o usposobieniu żywym i nazbyt śmiałym dobrze byłoby dołączyć bardziej rozważnego i powściągliwego; tak też należy postępować w innych sprawach co do doboru ludzi, by różnorodność złączona węzłem miłości stała się pomocą dla każdego z nich, a nie wywoływała rozdźwięku czy niezgody między nimi lub innymi ludźmi (Konstytucje 222).

Między G. Fernandesem i R. de Nobili było znacznie więcej różnic niż tylko doświadczenie i temperament. Na przeszkodzie ich porozumieniu stanęła klasa społeczna, narodowość i wykształcenie (Županov 4). Były żołnierz, oddany portugalskiej fladze, nie mógł pojąć, dlaczego młody, rzymski arystokrata odcina się od bycia parangi. Kiedy R. de Nobili zdecydował się na swoistą separację swego kościoła w 1607 r. od przybyłej z wybrzeża wspólnoty G. Fernandesa, rozpoczęła się trwająca wiele lat listowna dysputa pomiędzy Madurajem, Koczinem, Goa, Rzymem i Lizboną. Zapoczątkował ją G. Fernandes, oskarżając R. de Nobili o zbytnie przestrzeganie hinduskich zwyczajów, uwłaczanie honorowi Portugalii i nieprzestrzeganie jezuickich cnót: miłosierdzia, pokory i posłuszeństwa. Wobec takich zarzutów prawie każdy jezuita w Indiach czuł się w obowiązku opowiedzieć po jednej ze stron, a R. de Nobili, chcąc kontynuować swoją pracę, musiał wykazać słuszność swoich racji.

\section{Przybycie Roberta de Nobili do Maduraju}

Kiedy R. de Nobili przybył do Maduraju, potrzebował niewiele czasu, by zauważyć, że jego współbrat nikogo w mieście nie nawrócił. Starając się dociec przyczyny takiego stanu rzeczy, znalazł pomoc w osobie młodego, hinduskiego nauczyciela, który pracował w założonej przez G. Fernandesa szkole. Inteligentny i znający hinduistyczną teologię nauczyciel należał do stosunkowo wysokiej kasty. Miał jednak tak złą opinię o G. Fernandesie i jego religii, że nigdy nie rozmawiał z nim na tematy duchowe (Sauliére 42). Robert de Nobili chciał zdobyć jego przyjaźn i uzyskać pomoc w studiowaniu języka tamilskiego. Było to początkowo trudne, ponieważ nowego misjonarza rów- 
nież postrzegano jako parangi. Jednak dzięki rodzącemu się zaufaniu R. de Nobili dowiedział się, jakie nieakceptowalne przez Indusów błędy popełniali Portugalczycy. Nosili oni skórzane buty, tymczasem żaden bramin nie móg1 dotknąć czegokolwiek, co pochodziło od zabitego zwierzęcia; jedli za pomocą noża i widelca, co budziło odrazę, oraz pili wino, jedli mięso i - co najgorsze spożywali wołowinę. Ktokolwiek przyjmował ich wiarę, musiał także zmienić imię, sposób ubierania i jedzenia. Tak stawał się wyrzutkiem społeczeństwa i mógł liczyć tylko na towarzystwo Portugalczyków.

Dla R. de Nobili stało się więc jasne, że jeśli chce nawiązać kontakt z braminami, musi zrezygnować z europejskich zwyczajów. Uważał, że jeżeli uda mu się nawrócić przedstawicieli najwyższej kasty, reszta społeczeństwa podąży za ich przykładem. Na zmianę stylu życia potrzebował pozwolenia od prowincjała Alberta Laerzia, który z kolei musiał uzgodnić je ze swoim przełożonym. Francisco Ros, pochodzący z Katalonii arcybiskup Cranganore, okazał się gorącym zwolennikiem zachowania lokalnych zwyczajów. Chrześcijanie św. Tomasza w jego diecezji przyjęli swoją wiarę wiele wieków przed przybyciem Portugalczyków i nikt nie śmiał nazywać ich parangi. Żyli w sąsiedztwie hindusów i byli darzeni szacunkiem, stanowiąc oddzielną kastę, wysoką w hierarchii społecznej. Arcybiskup F. Ros prezentował postawę liberalną i tolerancyjną względem lokalnych tradycji. Pracując wśród chrześcijan św. Tomasza, uważał, że można oddzielić część zwyczajów od religii. Rozumiał niechęć i wątpliwości związane z koniecznością nabycia nowego imienia przez konwertytów $\mathrm{w}$ trakcie chrztu oraz $\mathrm{z}$ odrzuceniem tradycji pielęgnowanej przez pokolenia. Adaptacja lokalnych zwyczajów była powszechna od początku chrześcijaństwa.

Kiedy święty Piotr przybył do Rzymu czy narzucił rzymskim konwertytom swoje długie włosy, powiewną brodę i swój chałat? Jeśli ci Rzymianie z krótko obciętymi włosami, ogolonymi brodami i w swoich togach mogli być dobrymi chrześcijanami, dlaczego indyjscy konwertyci mają pozbyć się swojego sznura, kudumi i narodowych zwyczajów jako warunek wstępny do otrzymania chrztu? (Sauliére 46)

Zachęcony poparciem arcybiskupa A. Laerzia zaakceptował większość proponowanych zmian. Wyjątek stanowiła kwestia stroju. „Niech ojciec Roberto nazywa siebie jak chce, je na co ma ochotę i bywa, gdzie mu się podoba, lecz na miłość boską, nie pozwólmy mu ubierać się jak hinduski sannyasi" (Sauliére 47). Robert de Nobili zaprzestał więc jedzenia mięsa, zaczął nosić wyłącznie drewniane sandały, zatrudnił bramińskiego kucharza i zadowalał się jednym posiłkiem dziennie. Starał się także unikać osób z niższych kast, w tym chrześcijan G. Fernandesa. Aby pokazać, że nie ma nic wspólnego z pogardzanymi parangi, zaczął nosić sznur „,podwójnie urodzonych” 
kast, który szczegółowo opisywał A. Laerzio: „składa się on nie z trzech, lecz z pięciu części. Trzy z nich są złote i symbolizują Trójcę Świętą, a dwie białe, reprezentujące duszę i ciało Chrystusa, naszego Pana. Do tego sznura dołączony jest krzyż - znak męki i śmierci Jezusa Chrystusa. Tak więc ten sznur jest symbolem tajemnicy Trójcy Świętej, wcielenia i odkupienia" (Laerzio 54, ff 2-16, 17-75).

W tym czasie jego lekcje języka tamilskiego przerodziły się w rozmowy o zwyczajach indyjskich, a także o hinduizmie, chrześcijaństwie i poszukiwaniu jedynej prawdy. Szybkie postępy w nauce pozwoliły na podejmowanie coraz bardziej złożonych i skomplikowanych zagadnień ze sfery religijnej czy duchowej. „[Nauczyciel] spiera się ze mną na temat Boga, wędrówki dusz, stworzenia etc. I widząc, że rozsądek jest nie zawsze po jego stronie, stał się bardziej pokorny i darzący szacunkiem" (Nobili 51,3-6). Momentem przełomowym było zaćmienie Słońca, mające miejsce 25 lutego 1607 r. W tym dniu R. de Nobili i jego nauczyciel postanowili studiować nawzajem swoje religie przez 20 dni po pięć godzin dziennie. „Po tym, jak nauczałem go przez dwadzieścia dni, oznajmił, że jest usatysfakcjonowany pod każdym względem i poprosił, żebym go ochrzcił, co uczyniłem z wielką radością, bo był on pierwszym w tym mieście, który usłyszał Prawdę i ją przyją̧" (Nobili 51,3-6). W ten sposób R. de Nobili udzielił pierwszego chrztu, mianowicie w marcu 1607 r., zatem niespełna pół roku po przybyciu do Maduraju. Młody nauczyciel na cześć prowincjała A. Laerzia otrzymał imię: Albert. Jakiś czas później krewny Alberta, będący pandaraswami, usłyszał z przerażeniem, że jego kuzyn przyjął religię parangi. Po długiej dyskusji z R. de Nobili przekonał się, że nowy guru był najbardziej uczonym człowiekiem, jakiego kiedykolwiek spotkał. Od tego czasu stał się częstym gościem jezuity. Chrzest przyjmowało coraz więcej osób, lokalna wspólnota rozrastała się.

\section{Nowe miejsce zamieszkania}

Już w początkowym okresie pobytu w Maduraju wobec narastających niezgodności między R. de Nobili a G. Fernandesem ten pierwszy postanowił zamieszkać oddzielnie. Ponieważ G. Fernandes i popierający go jezuici z wybrzeża donosili A. Laerzio, że młody przybysz zachowuje się skandalicznie, prowincjał, który początkowo nie reagował na skargi, musiał wreszcie zająć jakieś stanowisko. W liście do generała donosił: „Opozycja wobec ojca Roberta była tak wielka, że napisałem do niego, aby nie udzielał więcej chrztów poganom do czasu, kiedy wyjaśnię pewne wątpliwości dotyczące jego sposobu ubierania, jedzenia posiłków etc., co zamierzałem zrobić przy okazji wizyty w Maduraju" (Laerzio 54, 2-16, 17-75). Prowincjał zjawił się w Maduraju pod 
koniec sierpnia $1608 \mathrm{r}$. i pozostał tam przez miesiąc. Miał za zadanie nie tylko uspokoić swoje sumienie w sprawie kontrowersyjnego podwładnego, lecz także zebrać argumenty, gdyby metody misjonarza znowu krytykowano. Zamieszkał u R. de Nobili i przyjął wszystkie obowiązujące tam zwyczaje. W liście do generała pisał, że R. de Nobili nosi żółtą szatę sięgającą ziemi, a biały materiał, owinięty wokół głowy, tworzy rodzaj turbanu. Opisywał dom, gdzie mieszkał R. de Nobili, i sposób, w jaki przyjmował on gości. O jego znajomości języka pisał, iż mówi najczystszym tamilskim i ma tak doskonałą wymowę, że nawet najbardziej wybredny bramin nie mógłby poprawić jego dykcji (Laerzio 54,2-16, 17-75). Był tak zadowolony z pracy R. de Nobili, iż dał mu pełne pozwolenie na otwarte nauczanie i udzielanie chrztu, i żałował, że na kilka miesięcy przerwał jego pracę apostolską.

Kolejnym krokiem misjonarza w poznaniu Indii był sanskryt. Tylko dzięki znajomości tego języka R. de Nobili mógł poznać istotę hinduizmu i prowadzić dyskusje z uczonymi braminami. Żaden Europejczyk przed R. de Nobili nie uczył się „łaciny braminów”, jak nazywano ten język. Uważano sanskryt za język liturgii, filozofii i nauki, ale niewiele więcej o nim wiedziano. W 1608 r. bramin Śivadharma zaczął uczyć R. de Nobili. Nauka sanskrytu opierała się głównie na pamięciowym opanowywaniu formuł przy braku wyjaśnień zasad gramatycznych. Był to język znacznie trudniejszy od tamilskiego, niesłużący do komunikowania praktycznych rzeczy, lecz stosowany do opisywania abstrakcyjnych idei. Jezuita musiał mieć jednak fenomenalną pamięć i niezwykłe umiejętności lingwistyczne. Prawdopodobnie już w sierpniu 1609 r. potrafił płynnie mówić i czytać (Neill 1984, 284). Robert de Nobili darzył swojego nauczyciela wielkim szacunkiem i nazywał go w listach: carissimo maestro. Niemożliwe byłoby poznanie braminizmu bez znajomości Wed, tak jak niemożliwe byłoby poznanie chrześcijaństwa bez czytania Biblii. Robert de Nobili poprosił więc o spisanie dla niego świętych pism, które bramin cytował podczas ich dyskusji. Znajomość Wed była przywilejem braminów, a wyjawienie świętych pism komuś z niższej kasty uznawano za wielki grzech. Robert de Nobili tak opisywał to zdarzenie w liście do prowincjała:

Musi Wasza Ekscelencja wiedzieć, że ci ludzie uważają spisywanie ich praw za najcięższy grzech. Dzieci muszą uczyć się ich na pamięć. Praca ta zajmuje im dziesięć czy dwanaście lat. Ale teraz mam dobrą sposobność, aby mieć je napisane przez mojego mistrza... Ponieważ jest on wielkim znawcą ich religii, nie możemy przepuścić takiej okazji, by zdobyć wiedzę o niej. Bez wątpienia musi to być czynione w największej tajemnicy, uwzględniając wielkie, osobiste niebezpieczeństwo z tym związane, ponieważ gdyby się dowiedzieli, z pewnością wyłupiliby mu oczy. Ponieważ jest to konieczne, ważne sposoby nawracania tych ludzi nie powinny być zaniedbane. Jest pewne, że nasz Pan pomoże mu we wszystkim i uchroni go od wszelkiego niebezpieczeństwa (Cronin 87). 
Śivadharma musiał mieć więc wielkie zaufanie do swojego ucznia, skoro po długich wahaniach zgodził się wyjawić R. de Nobili święte pisma. Nie wiadomo dokładnie, jaką część Wed udało mu się spisać. W ten sposób, około 2500 lat po ich skomponowaniu, pierwszy Europejczyk poznał Wedy. Utwory te są najstarszymi tekstami indyjskimi, uważanymi za śruti, czyli objawienie. Zapoczątkowują one literaturę i filozofię indyjską (Frauwallner 85). Powstały w dawnej formie sanskrytu i były przekazywane ustnie. Misjonarz pisał w grudniu 1608 r. do A. Laerzia, że dowiedział się, iż wcześniej nauczano pięć praw, z czego pozostały trzy: prawo Brahmy, Wisznu i Rudry (Sziwy). Czwarte było prawem duchowym, które uczyło ludzi, jak uzyskać zbawienie. Fragmenty tego prawa istnieją w pozostałych trzech, ale reszta zaginęła i nie ma kogokolwiek, kto byłby wystarczająco uczony i święty, by ją odnaleźć.

Poza tym najbardziej uczeni wśród tych ludzi twierdzą, że napisane jest w ich księgach, iż żadne $\mathrm{z}$ tych trzech praw nie może przynieść prawdziwego zbawienia, z czego niektórzy wyciągają wniosek, że nie ma żadnego życia poza doczesnym [...]. Mówię im, że przybyłem z dalekiego kraju z jednego powodu, aby uczyć ich tego prawa, które zaginęło (Cronin 90).

Roberto de Nobili adaptował naukę chrześcijańską dla indyjskich idei, tak jak św. Paweł zaadaptował swoje przesłanie dla idei Ateńczyków, mówiąc o „nieznanym Bogu”. Robert de Nobili przekonywał ludzi, że jeśli chcą odzyskać utracone Prawo, muszą stać się jego uczniami. Wszystkie sekty uznają trzy Prawa, lecz mają też swoich nauczycieli. Jezuita jako „zaginioną Wedę" czy Prawo rozumiał prymitywną religię objawioną ludzkości i zniszczoną przez grzech, wcieloną i udoskonaloną przez chrześcijańskie objawienie. W ten sposób zdecydował się na próbę przełożenia zasad wiary chrześcijańskiej na indyjski system pojęć i wyobrażeń. Jego przedsięwzięcie miało swój wzór w stylu misyjnym Mattea Ricciego, realizowanym w Chinach. Użył on konfucjańskich tekstów i zaakcentował w nich te doktryny, które były zgodne $\mathrm{z}$ chrześcijańskimi, jak również zinterpretował ambiwalentne teksty $\mathrm{w}$ taki sposób, by zgadzały się z chrześcijańskimi ideami.

\section{Nawrócenia na chrześcijaństwo czy podążanie za guru?}

Czy R. de Nobili rzeczywiście był uważany za głosiciela nowej religii, czy też za jednego z wielu guru, który przykładem świętego życia pociągał za sobą innych? Guru w tradycji indyjskiej to nauczyciel duchowy, przekazujący wiedzę o wyzwoleniu i wgląd w jego istotę. Ideę osoby przekazującej boską wiedzę odnajdujemy w Wedach i upaniszadach. Katoliccy misjonarze, poczynając od R. de Nobili, doceniali funkcje guru czy sannjasina. 
[O tym] że nikt, jak tylko prawdziwy mistrz duchowy, nie będzie w stanie wieść Indusów do chrześcijaństwa, wiedzieli pierwsi zachodni misjonarze w Indiach [...] [R. de Nobili] był uważany za guru ze swoim specyficznym nauczaniem i zgromadził wokół siebie wielu uczniów. Bramini ci przywiązani byli jednak mniej do Kościoła a bardziej do osoby R. de Nobili. W rezultacie niewielu pozostało chrześcijanami po jego śmierci (Cornille 130).

Catherine Cornille, profesor teologii porównawczej z Boston College, zarzuca R. de Nobili, że mimo iż wykazywał zrozumienie dla hinduistycznych tradycji religijnych, to jego podejście do wierzeń i systemów filozoficznych hinduizmu było poniżające. Jego wygląd guru był raczej podstępem, by nawrócić hindusów, a nie dowodem wiary w wartości i prawdę hinduistycznej tradycji. Niemniej jednak to on, jako pierwszy wykształcony chrześcijanin, zaczął dyskutować z braminami. Nie studiował ich ksiąg po to, żeby je krytykować czy wyśmiewać, ale w celu poznania ich przesłania. Podkreślał, że „ci ludzie nie są takimi ignorantami, za jakich niektórzy ich uważają” (Nobili 51,3-6). Często w pogardzie ma się to, co nieznane, o czym świadczyło przez stulecia podejście Europejczyków do innych kultur. Po przestudiowaniu hinduskich pism i spędzeniu czasu wśród uczonych braminów R. de Nobili nabrał przekonania, że można mieć do nich jedynie szacunek, nawet jeśli nie podziela się ich poglądów. Robert de Nobili chciał nawracać, gdyż taki cel miała jego nauka i wyjazd do Indii. Temu zadaniu poświęcił całe życie, rezygnując z wygód i bogactw w rodzinnym kraju.

Odrębną kwestię stanowi to, czy rzeczywiście bramińscy prozelici R. de Nobili rozumieli znaczenie przyjęcia chrztu? Konwertyci mieli inną koncepcję religii niż tę, jaką miał ich nauczyciel. Niewątpliwie jego charyzma, wiedza, znajomość języków i ogłada wywarły wielki wpływ na nowych uczniów i miały duże znaczenie podczas ich zdobywania. Jednak decydowali się oni na chrzest po wielokrotnym wysłuchaniu jego racji. Konwersje następowały pojedynczo, po dokładnym przemyśleniu tego kroku i dyskusjach z jezuitą, którego argumenty wydawały się im wystarczająco przekonujące. To ogromny kontrast z metodami choćby Franciszka Ksawerego i innych misjonarzy, którzy chrzcili masowo całe wioski.

W owym kontekście Stephen Neill, w swojej dwutomowej Historii chrześcijaństwa $w$ Indiach, zastanawiał się, co oznaczało przyjęcie chrztu dla młodych mężczyzn, którzy stawali się uczniami R. de Nobili (Neill 1984, 283). Niewątpliwie oznaczało to dla nich coś innego niż dla europejskich misjonarzy. W tym czasie wielu reformatorów religijnych działało na terenie Indii. Każda sekta miała swój rytuał inicjacji, zatem chrzest musiał wydawać się im czymś podobnym. Robert de Nobili jawił się jako jeden z wielu guru, jego argumentacja była przekonująca, a osobowość i maniery sprawiały, że łatwo 
zdobywał uczniów. Konwertyci mogli zachować zwyczaje swojej kasty; nie mogli jednak brać udziału w hinduistycznych ceremoniach.

\section{Opozycja i kontrowersje}

Poczynania R. de Nobili były zgodne z zasadami akomodacji, promowanymi i propagowanymi przez arcybiskupa Francisca Rosa. Zatwierdził on m.in. możliwość umieszczania pasty sandałowej na czole, uznając to za ozdobę ciała, a nie za symbol religijny, i skomponował błogosławieństwo, jakie miało być odmawiane przy jej nakładaniu. Jednak R. de Nobili zdawał sobie sprawę, że jest osamotniony w swojej pracy. W liście do A. Laerzia z 22 kwietnia 1609 r. pisał, że potrzebuje jak najszybciej współbrata przygotowanego na umartwienia. Podkreślał, że przystosowanie się do indyjskich zwyczajów jest zrazu trudne. Wspomniał także, że po jego śmierci byłoby bardzo utrudnione odzyskanie znajomości Wed, jaką zdobył. Robert de Nobili wysłał dwóch młodych chrześcijan z Maduraju na Wybrzeże Malabarskie z listem do prowincjała. Ich wiedza z zakresu tajemnic wiary chrześcijańskiej była najlepszym dowodem na to, że R. de Nobili dobrze wykonywał swoją pracę, natomiast ich spostrzeżenia z Malabaru zawierały uwagę, iż chrześcijanie św. Tomasza również trzymają się $\mathrm{z}$ dala od nowych, mieszkających w okolicy konwertytów $\mathrm{z}$ niższych klas. Zanotowano to z zadowoleniem, gdyż potwierdzało praktykę R. de Nobili.

Arcybiskup F. Ros udzielił uczniom R. de Nobili bierzmowania i obiecał pomoc dla misji. Wizyta odniosła oczekiwany efekt, gdyż znalazło się wielu chętnych na misję w Maduraju. Do posługi w tej odległej placówce wybrano Manuela Leitão. Przybył on do Maduraju w sierpniu 1609 r., ubrany już w szatę w kolorze ochry. Przygotowany na surowe życie na misji, nie spodziewał się jednak, że będzie siedział na podłodze, spożywając posiłki podane na liściu bananowca i używając palców zamiast sztućców. Mimo podziwu, jaki żywił dla R. de Nobili i jego oddania się misji, nie był w stanie przyzwyczaić się do jedzenia jednego posiłku dziennie. Miał też problemy z nauką języka tamilskiego, a R. de Nobili prawdopodobnie nie był wystarczająco cierpliwy dla kogoś, kto nie miał takich zdolności jak on. W rezultacie 12 czerwca 1610 r. R. de Nobili napisał w liście do Antonia Vico, że znowu jest sam (Nobili 54a,76-92).

Kolejny problem narósł, gdy przybyli z wybrzeża chrześcijanie z niższych kast oznajmili konwertytom R. de Nobili, że poprzez chrzest stracili swoją pozycję społeczną. Kilkunastu z nich przestało przychodzić do kościoła. Robert de Nobili zmuszony został do napisania Manifestu, w którym przedstawił swoje stanowisko w tej kwestii. Zapisał je po tamilsku na liściach palmowych 
i przybił do drzewa przed swoją siedzibą. Najważniejsze jego tezy brzmiały następująco:

Nie jestem parangi. Nie urodziłem się w kraju parangi i nigdy nie byłem związany z ich rasą [...]. Pochodzę z Rzymu, gdzie moja rodzina posiadała taką samą pozycję, jak szacowni radża mają w tym kraju [...]. Z tymi, którzy przychodzili rozmawiać ze mną, dyskutowałem tylko kwestie dotyczące zbawienia ich dusz. Rozprawiałem o istnieniu Boga i jego atrybutach, [o tym] że jest jeden w trzech Osobach, stworzył świat, ludzi i wszelkie inne rzeczy [...]. Prawo, które głoszę, jest prawem prawdziwego Boga [...]. Ktokolwiek mówi, że to jest prawo parangi, przeznaczone tylko dla niskich kast, popełnia bardzo wielki grzech, bo prawdziwy Bóg nie jest Bogiem tylko jednej rasy, ale Bogiem wszystkich. Musimy wyznać, że zasługuje, aby być czczonym przez wszystkich (Neill 1984, 288).

Fragment ten ukazuje komplikację językową, z jakiej nie do końca zdawali sobie sprawę F. de Nobili oraz jego poplecznicy i przeciwnicy. Słowo parangi dla mieszkańców Maduraju oznaczało chrześcijanina. Na Wschodzie Feringhi, Frankowie i słowa pochodne wskazywały od dawna na przybyszów z Europy, a więc chrześcijan. Robert de Nobili zakładał, że parangi oznaczało Portugalczyków, a więc on, jako Włoch, nie był jednym z nich.

Roberto de Nobili przestał nosić sznur na przełomie 1609 i 1610 r. W ten sposób osiągnął dwie rzeczy: przeciwnicy nie mogli krytykować go już za noszenie sznura, a po drugie stał się formalnie sannjasinem. Oznaczało to nie tylko szacunek wszystkich kast, ale i wiele wyrzeczeń, ponieważ tryb życia sannjasinów odbiegał znacznie od tego, do którego przyzwyczajeni byli europejscy duchowni. Do swoich ślubów ubóstwa, czystości i posłuszeństwa musiał dodać powstrzymywanie się od jedzenia mięsa, ryb, jaj, wina, pozbycie się krzeseł, butów, kapelusza, niemożność podróżowania na koniu oraz pozbycie się brody i kolczyków. Oznaczało to poszczenie każdego dnia do godziny szesnastej, kiedy to mógł spożyć swój jedyny posiłek. Nie rozstawał się za to z kijem, do którego przyczepiony był porzucony sznur oraz symbolizujący ubóstwo kawałek materiału (Sauliére 112). Posunięcie było tyleż radykalne, co skuteczne, gdyż w ciągu kilku miesięcy liczba konwertytów wzrosła do 50 (Nobili 51,13-14).

Po stracie M. Leitaõ R. de Nobili znów potrzebował towarzysza i pomocnika. W tym czasie w Koczinie przebywał jego przyjaciel z rzymskich lat, Antonio Vico. Pisał do R. de Nobili, by okazać mu współczucie, na co adresat odpowiedział „niech się dzieje wola boska. Ale ty powinieneś otrzymać od Boga, dzięki swoim modlitwom to, by przysłano cię tutaj, gdzie będziesz mógł zdziałać wiele dobrego, i żeby [Bóg] umocnił cię w tym pragnieniu" (Sauliére 128). List zakończył stwierdzeniem, że jest niezwykle istotne, aby prowincjał 
przysłał mu towarzysza i żeby był nim A. Vico. Albert Laerzio nie był skory do wysłania do Maduraju profesora teologii z Koczina. W końcu jednak A. Vico przybył do Maduraju w dniu 15 kwietnia 1610 r. i przez następne 28 lat był najwierniejszym towarzyszem i lojalnym stronnikiem R. de Nobili. Kiedy R. de Nobili napisał Responsio w odpowiedzi na zarzuty stawiane przez G. Fernandesa, A. Vico dodał swoją rozprawę $O$ metodzie, która jest używana w nowej misji w Maduraju, aby nawrócić niechrześcijan do Chrystusa (Vico 88-109), składającą się z wprowadzenia i siedmiu rozdziałów. Zaledwie miesiąc po swoim przyjeździe do Maduraju był w stanie odpowiedzieć na wszystkie zarzuty. Pisał, że zaangażował się od początku w powstanie misji i często konsultował się w jej sprawie. Wyjaśniał metodę i to, co oznacza miano: $p a-$ rangi. Odnosił się także do noszenia sznura, nowych ceremonii i oddzielenia kościołów. Uważał, że metoda ta jest miła Bogu i misjonarze powinni otrzymać na nią pozwolenie (Nobili 210).

Nie wszyscy jezuici pracujący w Indiach rozumieli i popierali nowatorstwo misji. Wśród plotek, które zaczęły krążyć o R. de Nobili, była nawet taka, która głosiła, że stał się on hinduistą. Jednak R. de Nobili postępował ostrożnie i konsultował każdą ze swoich decyzji z prowincjałem. Miał pozwolenie nie tylko arcybiskupa F. Rosa, ale powiadomiony był o nich również arcybiskup Goa Alexis Menzenes. Popierający R. de Nobili A. Laerzio zatrzymał się dwukrotnie w Maduraju: w 1608 i 1609 r. W tym czasie mieszkał z R. de Nobili, akceptował i naśladował jego sposób zachowania i tryb życia. Swoje pozytywne wrażenia odnotowywał każdorazowo w raporcie przesyłanym generałowi Claudio Aquavivie. Jego relacje pozostają niezwykle wartościowe, ponieważ przedstawiają bezpośrednie doświadczenie życia chrześcijańskiego sannjasina. Gonçalo Fernandes jednak nadal podważał publicznie metody pracy R. de Nobili (Anchukandam 31). Niechęć do sposobów pracy o. Roberta wyrażali także: Nicolas Pimenta - nowy wizytator, wysłany do Indii przez generała Aquavivę, oraz Pero Francisco, zwierzchnik prowincji malabarskiej. „Był on uprzedzony do metody zaadaptowanej przez o. de Nobili i chciał za wszelką cenę zabronić jej stosowania; inaczej mówiąc, jego intencją było zrujnowanie misji w Maduraju w jej początkach" (Besse 201). Miał więc R. de Nobili trzech zaciętych wrogów, i to głównie przez nich kolejne 12 lat jego działalności upłynęło na polemikach. Pierwszym pismem tego typu było Responsio z 1610 r., które stworzył w pośpiechu, w ciągu kilku tygodni, aby zdążyć wysłać je z Goa do Rzymu z jesienną flotą.

Jednym z zaciętych wrogów R. de Nobili był Cristóvão de Sá, arcybiskup Goa i następca A. Menzenesa, który oczekiwał od papieża jednoznacznego potępienia R. de Nobili i jego metod. Musiał się jednak rozczarować, kiedy papież nakazał mu spotkać się z arcybiskupem F. Rosem, R. de Nobili i najlepszymi teologami w Indiach, aby przedyskutować sporne kwestie i wy- 
słać dokładny raport do Rzymu. Konferencja rozpoczęła się w Goa 4 lutego 1619 r. i mimo że początkowo większość uczestników, z wyjątkiem F. Rosa, była przeciwko R. de Nobili, jego teologiczna argumentacja zdołała przekonać adwersarzy. Przed konferencją R. de Nobili rozdał uczestnikom swoją rozprawę Narratio, podpisaną również przez arcybiskupa F. Rosa (Nobili 1972). Wyjaśniał w niej swoje racje tak umiejętnie, że w końcu udało mu się wpłynąć na opinię uczestników zgromadzenia. Czterech obecnych na spotkaniu teologów stwierdziło, że, znając sprawę z drugiej ręki, potępiali metodę madurajską, lecz po przeczytaniu Narratio nie mogliby dalej sprzeciwiać się jej z obawy przed popełnieniem wielkiego grzechu. Ojciec André Palmeiro z Goa mówił w sposób następujący:

Kiedy byłem w Coimbrze [w Portugalii], głosiłem publicznie przeciwną opinię. Nienawidziłem sznura wielką nienawiścią. Tak więc, jak tylko zostałem mianowany wizytatorem prowincji malabarskiej, zdecydowałem w pierwszej instancji pozbyć się misji madurajskiej i wytrzebić wszelkie jej pozostałości. Ale po rozważeniu argumentów i racji ojca Roberta, czuję się zobligowany zmienić moje zdanie, a wraz z nim moje zamierzenia (Cronin 213).

Arcybiskup F. Ros przeczytał rozprawę głoszącą, że metoda stosowana przez o. Roberta nie jest ani nowa, ani niedorzeczna. Stosowano ją od czasów apostolskich i Kościół zezwalał nie tylko na akceptowanie tradycyjnych symboli społecznej rangi, ale też na ryty i ceremonie pogańskie, które pozbawiano ich bezbożnego znaczenia i zastępowano chrześcijańskimi odniesieniami. W celu przekonania tych, do których nie docierały argumenty rozumowe, wziął Biblię i przysiągł na nią, że elementy tradycji indyjskiej, podtrzymywane wśród członków misji madurajskiej, nie są zabobonami, a przyzwolenie na ich kontynuację nie tylko może, ale powinno być wydane. Notatki ze spotkania, prezentujące rozmaite stanowiska, przesłano do Rzymu. Papież Paweł V (1605-1621) otrzymał, zamiast jednego raportu, plik różnych listów i zapisków. Przez następne dwa lata papieska kuria zalana została listami dotyczącymi misji w Maduraju. Nie tylko Watykan nękany był sprawą misji, lecz również król Portugalii, do którego listy słał arcybiskup C. de Sá. Apelacje budziły niepokój R. de Nobili, A. Vica i arcybiskupa F. Rosa, jednak wielki inkwizytor Mascarenhas, przeczytawszy rozprawę F. de Nobili, stanął po jego stronie. Decyzja wielkiego inkwizytora zaakceptowana została przez katolickiego monarchę i wysłana do Rzymu. Zanim listy dotarły, Paweł V zmarł i jego miejsce zajął Grzegorz XV (1621-1623). Jedną z pierwszych decyzji, podjętych przez nowego papieża, było powołanie komisji do zbadania dokumentów nadesłanych z Goa. Peter Lombard, arcybiskup Armagh, który ze względów politycznych nie mógł wrócić do swojej rodzinnej Irlandii, spędził 
ponad rok na szczegółowym badaniu sprawy, a następnie napisał dwudziestodziewięciostronicowy raport, w ogromnej mierze przychylny dla R. de Nobili. Peter Lombard podkreślał jedynie, że wszelkie bałwochwalstwo musi być porzucone, a użycie indyjskich symboli nie może dawać okazji do utrwalania starych przesądów. W dniu 31 stycznia 1623 r. papież wydał Konstytucję apostolską Romane sedis antistes, w której zawarł pozytywną ocenę działalności misji madurajskiej:

Chcąc na tyle, na ile jest to możliwe, nie obrażając Boga i nie dopuszczając do skandalu wśród ludów, doprowadzić do nawrócenia tych narodów [...], zezwalamy tym pismem, mocą władzy apostolskiej, braminom i innym poganom, którzy nawrócili się i nawrócą się na wiarę, na to, by mogli przywdziewać i nosić sznur i kudumi jako wyróżnienie ich stanu i jako znak ich politycznego szlachectwa, ich funkcji, mogą również używać sandału do ozdabiania i ablucji do zachowania czystości ciał (Anchukandam 121-122; Dahmen 187-199).

\section{Późniejszy rozwój misji}

Pracę misjonarską R. de Nobili można podzielić na cztery okresy. Pierwszy obejmował pionierskie lata 1606-1610, kiedy tworzył on nową metodę i odnosił rychło niespodziewane sukcesy. Lata 1610-1623 był czasem kontrowersji i pracy przerywanej ciągłym pisaniem listów oraz wyjazdami. Trzeci okres w historii misji, 1623-1645, charakteryzował się jej rozwojem tudzież przezwyciężaniem pojawiających się poważnych trudności. Robert de Nobili podupadał na zdrowiu, tracił wzrok, co utrudniało pracę i pisanie. Niestabilna sytuacja polityczna w Maduraju także nie sprzyjała pracy misyjnej.

Dla misji istotna zmiana nastąpiła w 1626 r., kiedy to. R. de Nobili spotkał członka niskiej kasty, należącego do sekty Valluvar (Neill 1984, 294), co pozwalało mu na pełnienie funkcji kapłana dla swojej społeczności. Mimo iż kapłan teoretycznie wyraził chęć przyjęcia chrześcijaństwa, R. de Nobili żywił wątpliwości ze względu na pochodzenie społeczne adepta. Do tej pory miał do czynienia tylko z przedstawicielami wysokich kast, starannie unikając kontaktu z ludźmi, których dotknięcie oznaczałoby skalanie. Szczerość wyznania kapłana, jego pokora i gorliwość skłoniły jednak o. Roberta do udzielenia mu chrztu (kapłan prawdopodobnie ochrzczony został pod koniec 1626). Dzięki temu precedensowi wielu jego uczniów zostało chrześcijanami; wkrótce było ich więcej niż chrześcijan wywodzących swoje pochodzenie z wyższych kast.

W tym czasie razem z R. de Nobili pracowali na misji: A. Vico i Emmanuel Martins. Emmanuelowi Martinsowi nie odpowiadała sytuacja, w której dzielił swój czas między wiernych braminów i ludzi z niższych kast, spotyka- 
jąc jednych w ciągu dnia, a drugich po kryjomu w nocy. Zdecydował się więc pozostawić misję R. de Nobili dwóm towarzyszom i zająć się wyłącznie biedniejszymi chrześcijanami. Była to jego osobista decyzja, ale wraz z rosnącą liczbą konwertytów z niższych kast należało na stałe rozwiązać zaistniały problem. Wspólnota skupiała przedstawicieli kast wyższych, którymi zajmowali się jezuiccy sannjasini. Gdyby zajęli się oni również służbą niższym klasom, bramini mogliby opuścić wspólnotę. W 1644 r. było 1208 konwertytów z wyższych kast oraz 4183 z niższych (Jeyaseela 59).

Roberto de Nobili zauważył, że oprócz sannjasinów, byli też inni kapłani, nazywani pandāram. Nie musieli oni zachowywać wszystkich przepisów tak jak bramini, którym zakazano kontaktów z niższymi kastami. Jak pisał Augustin Sauliére, pandāram traktowani byli jako oddzielna klasa społeczna i nikt nie dociekał, do jakiej należą kasty. Byli traktowani po prostu jako swami, czyli nauczyciele religijni (Sauliére 437). Aczkolwiek R. de Nobili, A. Vico i E. Martins mieli stosować się do zakazów i nakazów wyższych kast, możliwa byłaby współpraca z pandāraswami, którzy pracowaliby z ludźmi z niższych kast. Robert de Nobili skonsultował swój nowy zamysł z arcybiskupem i prowincjałem i otrzymał zgodę na poszerzenie kręgu uczniów. Pierwszym pandāraswami został Balthasar da Costa. Z zapałem zabrał się do pracy i przez trzy lata ochrzcił około dwa tysiące osób. Wydaje się, że B. da Costa uważał swoją pracę za bardziej zgodną z duchem chrześcijaństwa niż ekskluzywizm R. de Nobili, jednak w liście z 1644 r. pisał o swoim przełożonym z entuzjazmem: „Jakim człowiekiem jest o. Nobili! Jakim modelem dla wszystkich misjonarzy! Im starszy, tym wiek dodaje do jego życiowego autorytetu i świetności jego apostolskim zasługom. Prawie niewidomy i przytłoczony fizycznymi słabościami, pracuje jak najbardziej gorliwie i jest oddany z młodych misjonarzy, jego zapał dostarcza siły, której brakuje jego ciału" (Da Costa 53, ff. 127-42; ff. 143-61). Ojcu Balthasarowi zawdzięczamy też jeden z niewielu portretów R. de Nobili, ukazujący sposób, w jaki o. Roberto zaadaptował wygląd sannjasina.

Ostatnie lata życia R. de Nobili przyniosły trudne doświadczenia. Po 1640 r., wraz z innymi jezuitami, stał się ofiarą wrogości ze strony miejscowych władz i został nawet uwięziony za prozelityzm. W 1646 r., w wieku 70 lat, przeniesiony został decyzją swoich przełożonych z ukochanego Maduraju na Cejlon. Trzy lata później nakazano mu przenieść się do Mylapore (Neill 1984, 297). Zamieszkał z dala od miasta, gdzie wraz z czterema chrześcijańskimi braminami oddawał się dyskusjom dotyczącym zagadnień poruszanych w jego pismach. Mimo nękających go chorób i utraty wzroku jego umysł pracował sprawnie. W styczniu 1656 r. zakończył dyktowanie i po upływie kilku dni, 16 stycznia, zmarł. Prawdopodobnie jego ciało zostało, hinduistycznym zwyczajem, skremowane. 
W chwili śmierci o. Roberta było około dwustu ochrzczonych braminów. Jednak nie wszyscy oni pozostali wierni po odejściu ich guru. Liczba wszystkich konwertytów na terenie misji z pewnością przekraczała czterdzieści tysięcy osób. Wysiłki B. da Costy oraz jego otwartość względem rozmaitych grup społecznych przyczyniły się znacznie do rozrostu misji madurajskiej. Pionierska praca R. de Nobili przygotowała owocny grunt pod dalsze próby nawracania ludności indyjskiej. Niewielu jednak decydowało się na naśladowanie wymagającego życia sannjasina, stąd niełatwo było znaleźć chętnych do kontynuacji pracy R. de Nobili. Ostatnim z nich był o. Joseph Arcolino, który zmarł w $1676 \mathrm{r}$.

Po śmierci R. de Nobili jedynym źródłem informacji o misji pozostały $L i$ sty roczne, do których pisania zobowiązani byli jezuici $\mathrm{w}$ dalekich zakątkach globu. Dowiadujemy się z nich, że powtarzającym się problemem misji była mała liczba misjonarzy. Raport z 1666 r. wspomina tylko o pięciu ojcach. Misja rozrastała się terytorialnie i w $1678 \mathrm{r}$. należało do niej 13 rezydencji rozrzuconych w pewnej odległości od Maduraju, w tym pięć z nich niezamieszkałych. W następnym roku było siedmiu misjonarzy, a w 1683 r. dziewięciu. W tej sytuacji część pracy przejmowali indyjscy katecheci. Balthasar da Costa pisał w swoim pierwszym Liście rocznym, że katecheci otrzymywali małą pensję, aby mogli utrzymać siebie i swoje rodziny (Bertrand 318). Balthasar da Costa podkreślał w swoich rozważaniach, że pomysł prowadzenia nauczania przez konwertytów nie powstał w Maduraju, ale wykorzystywano go z powodzeniem już w Japonii (Neill 1990, 135). Nie byli w żaden sposób szkoleni, lecz posługiwali się pewnymi tekstami przygotowanymi przez R. de Nobili.

\section{Oryginalność i nowatorstwo Roberta de Nobili}

Spory o obrzędy czy ryty malabarskie, jak określano metodę R. de Nobili, zezwalającą neofitom na zachowanie ich zwyczajów, toczyły się jeszcze długo. Jan de Britto, który stosował tę metodę, został beatyfikowany. Jednak późniejsze dekrety papieskie, takie jak np. bulla Benedykta XIV z 1744 r., zakazały rytów malabarskich, mimo protestów pracujących w Indiach duchownych.

Chociaż R. de Nobili odrzucał tezę, że wszystkie religie są drogami do zbawienia, brał pod uwagę kwestię zbawienia niechrześcijan (Brockington 169). Argumentował, że Bóg w swoim miłosierdziu nie potępi dobrego niechrześcijanina. Jego zasługi nie zapewnią mu zbawienia, ale może do niego przyjść boska zbawcza łaska. Wprawdzie R. de Nobili myślał, pisał i działał w celu nawracania, a nie prowadzenia dialogu międzyreligijnego, należy jednak pamiętać, że była to pierwsza połowa XVII w., a więc był misjonarzem na długo przed tym, kiedy zaczęło funkcjonować pojęcie dialogu międzyreligijnego. 
Był też wybitnym myślicielem, wyprzedzającym swoją epokę o co najmniej trzy stulecia. Nie należy dziwić się, że hierarchowie kościelni mieli trudności z zaakceptowaniem jego metod. Dopiero w XX w. myśl katolicka zaczęła podążać torem dialogu i pojednania. Także styl życia jezuity był na tyle wymagający, że znalazło się niewielu chętnych do tak surowych wyrzeczeń.

\title{
ROBERTO DE NOBILI SJ AND THE MISSION IN MADURAI FROM 1606 TO 1656
}

\begin{abstract}
The Mission in Madurai 1606-1656 was a unique episode in the history of Christianity in India. During these times changing religion to Christianity meant abandoning one's culture. Roberto de Nobili, an Italian Jesuit and founder of the mission was the first European to learn Sanskrit, study the scriptures of the Vedas and convert Brahmins. He allowed them to keep their social customs, which was seen as controversial by the church hierarchy. He followed these social rules himself, living the life of an Indian ascetic and thus gaining respect among higher castes. His way of separating Hinduism from Indian culture was, and still is, contentious but it was done for practical purposes. The controversies forced him to defend his arguments on many occasions. In his writings he described Indian traditions and explained his method of missionary work. There were not many followers of de Nobili's method, who would be able to understand the need of accommodation, undertake studies of Hinduism and be prepared to embrace an ascetic lifestyle. It was not until the $20^{\text {th }}$ century that interreligious dialogue emerged as a concept and some Catholic clergymen found inspiration in Hindu spirituality. The goal of this thesis is to show just how pioneering was the accommodation method used by de Nobili and how his influence can still be felt on attempts at interreligious dialogue in the modern era.
\end{abstract}

Keywords: India; missions; Jesuits; accommodation; interreligious dialog

Słowa kluczowe: Indie; misje; jezuici; akomodacja; dialog międzyreligijny

\section{BIBLIOGRAFIA}

Anchukandam, Thomas. Roberto de Nobili's Responsio, 1610. A Vindication of Inculturation and Adaptation. Bangalore: Kristu Jyuti Publications, 1996.

Archivum Romanum Societatis Iesu (ARSI):

Balthasar da Costa. Relatione del successo nella missione de Madurè dalli Luglio 1643 infino a 29 d'ottobre 1644, Trigerapali, Goa 53, ff. 127-42; ff. 143-61. 
Nobili, Roberto de do Aquavivy. 1 grudnia 1607, Goa 51, ff. 3-6.

Nobili, Roberto de do Laerzio. 20 lutego 1609, Goa 54, ff. 1-16; ff. 17-75.

Nobili, Roberto de do Antonio Vico. Maduraj, 12 czerwca 1610, Goa 54a, ff 76-92.

Nobili, Roberto de do Fabio de Fabiis. 8 listopada 1609, Goa 51, ff.13-14,

Vico, Antonio. De modo quo nostra missio Madurensis utitur ad ethnicos Christo convertendos,

Goa 51, ff. 88-109.

Laerzio do Aquavivy, 20 listopada 1609, Goa 54, ff. 2-16, 17-75

Nobili, Roberto de do Aquavivy, Maduraj, 1grudnia, 1607, Goa 51, ff.3-6

Besse, Leon. La Mission Du Maduré: Historique De Ses Paangous. Trichinopoly: Mission Catholique, 1914.

Brockington, John, Hinduism and Christianity. London: The Macmillan Press, 1992.

Butryn, Roksana. „Bramini w liście Świętego Franciszka Ksawerego Sociis Romae degentibus, Cocino 15 Ianuarii 1544." Studia Indologiczne t. VIII (2001): ss. 5-24.

Cornille, Catherine. The Guru in Indian Catholicism: Ambiguity or Opportunity of Inculturation? Louvain: Peeters Press, Wm. B. Eerdmans Publishing, 1991.

Cronin, Vincent. A Pearl to India: The Life of Roberto de Nobili. Londyn: Rupert Hart-Davis Dutton, 1959.

Dupuis, Jacques. Chrześcijaństwo i religie. Od konfrontacji do dialogu. Kraków: Wydawnictwo WAM, 2003.

Frauwallner, Erich. Historia filozofii indyjskiej. Warszawa: PWN, 1990.

Jeyaseela, Stephen S. Caste, Catholic Christianity, and the Language of Conversion: Social Change and Cultural Translation in Tamil Country, 1519-1774. Delhi: Kalpaz Publications, 2008.

Kieniewicz, Jan. Historia Indii. Wrocław: Ossolineum, 1985.

Konstytucje Towarzystwa Jezusowego wraz z przypisami Kongregacji Generalnej XXXIV oraz Normy Uzupetniające zatwierdzone przez tę sama Kongregację. Kraków: Wydawnictwo WAM, 2001.

Krzesiński, Andrzej. Problem misji katolickich na Dalekim Wschodzie. Poznań: Księgarnia św. Wojciecha, 1939.

Kudelska, Marta, Karman i Dharma. Wizja świata w filozoficznej myśli Indii. Kraków: Wydawnictwo UJ, 2001.

Neill, Stephen. A History of Christian Missions. London: Penguin Books, 1990.

Neill, Stephen. History of Christianity in India. 1 vol. Cambridge: Cambridge University Press, 1984.

Nobili, Roberto de. Adaptation. Red. Savarimuthu Rajamianickam. Palayamkottai: De Nobili Research Institute, 1971.

P. $R$ de Nobili, L'apôtre des Brahmes: Première Apologie (1610). Red. Pierre Dahmen. Paryż: Bibliothèque des Missions, Mémoires et documents, 1931.

Roberto de Nobili on Indian Customs (Narratio). Red. Savarimuthu Rajamianickam. Paloyamkottai: De Nobili Research Instiutute, 1972.

Sauliére, Augustin. His Star in the East. Anand, Gujarat: Gujarat Sahitya Prakash, 1995.

Szczęsna-Perzyńska Maria. O. Roberto de Nobili TJ, apostoł Indii. Warszawa: Ogólnopolski Ośrodek Papieskich Dzieł Misyjnych, 1985.

Justyna Pyz, dr, etnolog, absolwentka Uniwersytetu Jagiellońskiego, związana przez wiele lat z Trinity College w Dublinie. Zajmuje się edukacją międzykulturową. Autorka artykułów o tematyce antropologicznej i misyjnej. Najnowsza publikacja: „Ethnography and ethnicity: Polish”, Joep Leerssen (ed.), Encyclopedia of Romantic Nationalism in Europe, Amsterdam: Amsterdam University Press, 2018. 